\title{
Hospital readmissions in late preterm infants
}

\author{
Marco Pezzati \\ From XX National Congress of the Italian Society of Neonatology \\ Rome, Italy. 9-11 October 2014
}

Neonatologists generally recognize that late preterm infants face more problems in the immediate newborn period compared with their full-term counterparts. [1,2]. This excess morbidity extends beyond the initial birth hospitalization [3] and the literature recognizes that readmission rates of late preterm infants are 1.5 to 3 times that of term infants [4-7]. In this group of infants, the overwhelming reasons for rehospitalisation are jaundice and feeding problems.

The most widely studied metric of health care utilization in late preterm infants is short-term readmission (the first two weeks) after birth hospitalization. Escobar [8] found that late preterm babies with short NICU stays had the highest rehospitalisation rates and in a follow-up study they found that rehospitalisation rates within 2 weeks were higher among late preterm infants who never were admitted to the NICU [4]. Shapiro-Mendoza [7] found that late preterm babies discharged early were at greater risk of neonatal morbidity. They also found that risk factors for subsequent readmissions were birth hospital stays less than 4 days, breastfeeding, Asian/ Pacific Islanders, first born infants, and public payers at the time of delivery. In the United Kingdom, Oddie [9] also noted that late preterm infants had the highest rate of readmission but infectious disease and not jaundice was the leading factor for readmission, which the investigators attributed to a differing approach to management of jaundice in the United Kingdom.

Escobar[10] examined late rehospitalisation (after the first two weeks) and found 36 week gestation newborns at higher risk for readmission. Paradoxically, babies of 34 and 35 weeks were not at higher risk and this may be explained by more frequently delayed discharge of infants of shorter gestational age. McLaurin [5] also demonstrated increased late rehospitalisation rates in late preterm infants and found that the subset with prolonged birth hospitalizations ( $\geq 4$ days) had the highest rates of

Neonatology and NICU, Ospedale San Giovanni di Dio, ASL 10 Firenze, Italy rehospitalisation. Respiratory disease (bronchiolitis and pneumonia) was the most common cause of readmission.

The late preterm infant is particularly responsive to the benefits but vulnerable to the risks of early discharge home. Longer length of stay before discharge is protective against readmission but it is not reasonable to prolong the birth hospitalization of newborns who meet criteria for discharge. More effort needs to be placed to reduce the risk of jaundice and feeding problems in these patients: to avoid mother and infant separation during birth hospitalization, to arrange a follow-up appointment within 48 hours of discharge, to promote and support lactation before and after discharge.

Conflict of interest

The author has no conflict of interest to declare.

Published: 9 October 2014

\section{References}

1. Mclntire DD, Leveno KJ: Neonatal mortality and morbidity rates in late preterm births compared with births at term. Obstet Gynecol 2008, 111(11):35-41.

2. Gouyon JB, Vintejoux A, Sagot P: Neonatal outcome associated with singleton birth at 34-41 weeks of gestation. Int J Epidemiol 2010, 39:769-76.

3. Kuzniewicz MW, Parker SJ, Schnake-Mahl A, Escobar GJ: Hospital readmissions and emergency department visits in moderate preterm, late preter, abd early term infants. Clin Perinatol 2013, 40:753-775.

4. Escobar GJ, Greene JD, Hulac P: Rehospitalization after birth hospitalization: patterns among infants of all gestations. Arcc Dis Child 2005, 90:125-31.

5. MCLaurin KK, Hall CB, Jakson EA: Persistence of morbidity and cost differences between late-preterm and term infants during the first year of life. Pediatrics 2009, 123:653-9.

6. Martens PJ, Derksen S, Gupta S: Predictors of hospital readmission of Manitoba newborns within six weeks postbirth discharge: a populationbased study. Pediatrics 2004, 114:708-13.

7. Shapiro-Mendoza CK, Tomashek KM, Kotelchuck M: Risk factors for neonatal morbidity and mortality among "healthy", late preterm newborns. Semin Perinatol 2006, 30:54-60.

8. Escobar GJ, Joffe S, Gardner MN: Rehospitalization in the first two weeks after discharge from the neonatal intensive care unit. Pediatrics 1999 , 104:e2.

9. Oddie SJ, Hammal D, Richmond S: Early discharge and readmission to hospital in the first month of life in the NorthernRegion of th UK during 1998: a case cohort study. Arch Dis Child 2005, 90:119-24. 
10. Escobar GJ, Clark RH, Greene JD: Short-term outcomes of infant born at 35 and 36 weeks gestation: we need to ask more questions. Semin Perinatol 2006, 30:28-33.

doi:10.1186/1824-7288-40-S2-A29

Cite this article as: Pezzati: Hospital readmissions in late preterm infants. Italian Journal of Pediatrics 2014 40(Suppl 2):A29.

Submit your next manuscript to BioMed Central and take full advantage of:

- Convenient online submission

- Thorough peer review

- No space constraints or color figure charges

- Immediate publication on acceptance

- Inclusion in PubMed, CAS, Scopus and Google Scholar

- Research which is freely available for redistribution 